\title{
IDENTIFIKASI DAN INVENTARISASI USAHA AGRIBISNIS \\ DI SEKITAR KAWASAN HUTAN KECAMATAN SEJANGKUNG KABUPATEN SAMBAS KALIMANTAN BARAT
}

ABDUL HAMID A. YUSRA, RAKHMAD HIDAYAT

Staf Pengajar Jurusan Sosial Ekonomi Pertanian Fakultas Pertanian UNTAN

\section{ABSTRACT}

The aims of this research were: (1) to determine the types of existing agribusiness around forest areas, (2) to determine the agribusiness system that goes around forest areas (3) To determine the factors that affect the farm income communities around the forest areas in sub district Sejangkung.

The results showed that (1) Traditional and semi subsistance farming activities that carried out by the forest communities is food crops (rice) and poultry. Commercial farming is rubber and coconut. (2) The style farming communities around the forest areas still hereditary, traditional, using family labor, own capital and marketed their crops to middlemen or directly sold to the market sub-district or district level. (3) Revenue farming communities around the forest are included in the category of lower middle income. The lowest income level is Rp. 500.000/month and the highest is Rp. 3.000.000/month, with an average total income is Rp. 1.436.667/month.

Based on the results of the regression analysis, the factors that affect farm income are land area and capital. Factors that not affect the farm income are age, level of education, family size, farming experience, and labor.

Keywords: Agribusiness, Community around forests, Farmers income 


\section{PENDAHULUAN}

\section{Latar Belakang}

Masyarakat yang berdomisili di sekitar hutan umumnya bermatapencaharian di bidang pertanian, sebagai petani (berladang / bersawah dan berkebun). Selain bertani juga hidup dan bekerja dengan usaha sampingan antara lain meramu hutan, mencari ikan, berburu dan banyak juga terlibat sebagai karyawan atau buruh HPH, Perkebunan sawit dan buruh pertambangan (dengan surat ijin) maupun yang tanpa ijin (pertambangan liar/ PETI). Berbagai aktivitas yang telah dilakukan di atas merupakan salah satu penyebab terjadinya degradasi fungsi hutan dan lahan yang mengalami erosi dan sedimen tinggi, menciptakan lahan kritis. Fakta memperlihatkan telah terjadi kerusakan hutan dan lahan kritis di Kalbar tercatat 4.109.034,8 hektar (27,98\%) dari luas lahan Kalimantan Barat 14.680.700 hektar. Lahan kritis tersebut tersebar di dalam kawasan hutan 1.741.001,6 hektar dan 2.368.033.2 hektar di luar kawasan hutan (Dinas Kehutanan Propinsi KAL-BAR, 1999).

Untuk mengurangi kerusakan hutan yang lebih parah, telah dilakukan upaya pencegahan dan perbaikan hutan yang dirangkaikan dengan upaya peningkatkan taraf hidup masyarakat yang hidup dan berdomisili di sekitar kawasan hutan, namun belum mampu mengimbangi terjadinya kerusakan hutan dan lahan. Kaitannya dengan hal di atas maka pada tahun 2002 telah dikeluarkan kebijakan penyusunan Master Plan Rehabilitasi Hutan Dan Lahan (Mp-Rhl) Daerah oleh Badan Planologi Kehutanan dengan sasaran strategis :

a. Terciptanya transparasi dan keterpaduan dalam perencanaan, pelaksanaan dan evaluasi kegiatan $\mathrm{RHL}$;

b. Terwujudnya komitmen bersama penanganan/pengelolaan SDH dan lahan;

c. Terwujudnya kesamaan persepsi, strategi, kelembagaan dan peran para pihak dalam penanganan $\mathrm{RHL}$;

d. Diketahuinya kondisi nyata SDH dan lahan daerah;

e. Terwujudnya pelaksanaan $\mathrm{RHL}$ yang efektif dan efisien;

f. Tersedianya informasi SDH dan lahan bagi para pihak/investor;

g. Berkembangnya partisipatif aktif masyarakat

Adapun manfaat dari Penyusunan Master Plan Rehabilitasi Hutan Dan Lahan (MpRhl) Daerah adalah :

a. sebagai acuan untuk perencanaan yang lebih detail, pengendalian dan evaluasi pelaksanaan

kegiatan rehabilitasi hutan dan lahan.

b. sebagai dasar komitmen bersama dalam penanganan kegiatan rehabilitasi hutan dan lahan.

c. sebagai acuan dalam perencanaan dan pengalokasian pendanaan $\mathrm{RHL}$.

d. sebagai sumber data dan informasi bagi para pihak/investor

Berpedoman pada Master Plan RLKT ini, banyak program yang sudah dilaksanakan, antara lain, program Hutan Kemasyarakatan, Hutan Rakyat, Agro forestry dan $\mathrm{HTI}$ yang sampai sekarang masih berjalan. Selain difasilitasi oleh pemerintah, kegiatan penanaman pohon juga dilakukan secara mandiri oleh masyarakat, seperti menanam padi, karet, kopi dan lada. Baberapa tahun terakhir diketahui masyarakat juga sudah menanam kelapa sawit pada lahan pribadi yang menunjukkan usaha agribisnis 
sudah mulai dijalankan secara mandiri oleh masyarakat. Selain menanam berbagai jenis tanaman, beberapa anggota masyarakat juga bekerja sebagai buruh pertambangan emas baik dengan izin maupun tanpa izin.

Adanya berbagai program dan kegiatan yang sudah dilaksanakan oleh pemerintah maupun oleh anggota masyarakat, maka harapan berikutnya adalah masyarakat tidak lagi menggangu kelestarian hutan dan lahan, baik dengan cara menebang pohon, perladangan berpindah maupun dengan melakukan kegiatan pertambangan liar. Walaupun sudah banyak kebijakan pemerintah yang bermaksud mendorong perekonomian rakyat, namun fakta di lapangan menunjukkan masih banyak masyarakat sekitar hutan yang hidupnya miskin.

Fakta di lapangan memperlihatkan banyak usaha pertanian atau usaha agribisnis yang sudah dilakukan oleh masyarakat namun produksi yang dihasilkan masih relatif rendah yang menyebabkan rendahnya kesejahteraan mayarakat khususnya yang berada di kawasan sekitar hutan baik yang berdomisili di dalam maupun di luar kawasan hutan.

Akhirnya muncul pertanyaan, mangapa produktivitas usahatani mereka rendah dan mengapa kebun karet yang sudah dibangun kurang dirawat dan bahkan tidak dirawat sama sekali. Sehubungan dengan hal ini maka pertanyaan yang perlu dijawab dalam penelitian ini yang mendorong dilakukannya penelitian ini adalah :

a. Jenis usaha agribisnis apa yang sudah dilakukan oleh masyarakat di sekitar hutan dan berapa luas lahan yang mereka usahakan.

b. Bagaimana teknik budidaya yang dilakukan.

c. Berapa produktivitas dan keuntungan dari usaha yang sudah dilakukan dan berapa persen pendapatan yang diperolah dari usaha tersebut dapat menyumbang pengeluaran konsumsi primer mereka.

d. Bagaimana pengolahan hasil yang mereka lakukan.

e. Dimana mereka menjual hasil dan bagaimana sistem pembayaran serta daya tawarnya.

f. Darimana mereka memperoleh modal dan bagaimana sistemnya.

g. Bagaimana status kepemilikan lahan dimana letak posisi lahan yang diusahakan,

Terkait dengan hal di atas, maka penelitian mengenai Identifikasi dan Inventarisasi Usaha Agribisnis di Sekitar Kawasan Hutan sangat penting dilakukan, guna memberikan gambaran awal serta melakukan analisis pengembangan usaha agribisnis di masa yang akan datang.

\section{Tujuan Penelitian}

Berdasarkan latar belakang dan permasalahan yang sudah diuraian di atas, maka dapat dirumuskan tujuan penelitian sebagai berikut :

1. Ingin mengetahui jenis usaha agribisnis yang sudah ada di sekitar kawasan hutan.

2. Ingin mengetahui sistem agribisnis yang dilakukan oleh masyarakat di sekitar kawasan hutan.

3. Mengetahui faktor-faktor yang mempengaruhi pendapatan usahatani masyarakat di sekitar hutan Kecamatan Sejangkung Kabupaten Sambas 


\section{METODE PENELITIAN}

Metode dasar yang digunakan di dalam penelitian ini adalah metode deskriptif analitis yaitu suatu metode dalam meneliti status kelompok manusia, suatu objek, suatu set kondisi tertentu, suatu sistem pemikiran ataupun suatu kelas peristiwa pada masa sekarang, yang bertujuan untuk membuat deskripsi, gambaran atau lukisan secara sistematis, faktual dan akurat mengenai fakta-fakta, sifat-sifat serta hubungan antar fenomena yang diselidiki. (Nazir, 1999).

Lokasi penelitian ditentukan dengan sengaja yaitu di Kecamatan Sejangkung Kabupaten Sambas dengan pertimbangan bahwa terdapat banyak usaha agribisnis yang dilakukan oleh masyarakat di sekitar hutan. Sampel diambil sekitar 30 responden dengan metode pengambilan sampel secara acak sederhana (simple random sampling)

\section{Metode Analisis Data}

Untuk mengetahui faktor - faktor yang mempengaruhi pendapatan usahatani masyarakat di sekitar hutan digunakan analisis regresi linier berganda dengan metode Ordinary Least Square (OLS) dirumuskan sebagai berikut (Widarjono, 2000) :

$\ln \mathrm{y}_{\mathrm{i}}=\beta_{0}+\beta_{1} \ln \mathrm{X}_{1}+\beta_{2} \ln \mathrm{X}_{2}+\beta_{3} \ln \mathrm{X}_{3}+\beta_{4} \ln \mathrm{X}_{4}+\beta_{5} \ln \mathrm{X}_{5}+\beta_{6} \ln \mathrm{X}_{6}+\beta_{7} \ln \mathrm{X}_{7}+\mathrm{i}$

Keterangan :

$$
\begin{aligned}
& \mathrm{y}_{\mathrm{i}}=\text { Pendapatan (Rp/bulan) } \\
& \beta_{0}=\text { intersep } \\
& \beta_{1}-\beta_{7}=\text { koefisien regresi } \\
& \mathrm{X}_{1}=\text { Umur (ha) } \\
& \mathrm{X}_{2}=\text { tingkat pendidikan (tahun) } \\
& \mathrm{X}_{3}=\text { jumlah anggota keluarga (orang) } \\
& \mathrm{X}_{4}=\text { pengalaman (tahun) } \\
& \mathrm{X}_{5}=\text { Luas Lahan (liter) } \\
& \mathrm{X}_{6}=\text { Modal (Rupiah/bulan) } \\
& \mathrm{X}_{7}=\text { Tenaga Kerja (orang) } \\
& \mathrm{i}=\text { residual }
\end{aligned}
$$

\section{HASIL DAN PEMBAHASAN}

\section{Identitas Responden}

\section{Umur}

Salah satu kriteria yang menentukan kemampuan fisik petani adalah umur, makin tinggi umur petani seletah melewati umur produktif, maka kemampuannya dalam mencurahkan tenaga kerja semakin berkurang. Petani yang berumur muda dan sehat mempunyai kemampuan fisik yang lebih baik dan lebih cepat menerima adopsi ide-ide atau teknologi baru dibandingkan petani yang lebih tua. Selanjutnya Widyastuti (2000), mengelompokkan umur petani menjadi 3 golongan, yaitu usia muda (0-14 tahun), usia produktif (15-64 tahun) dan usia tua (65 tahun ke atas). Berdasarkan hasil penelitian menunjukkan umur petani responden bervariasi antara 19 - 66 tahun. 
Adapun persentase petani yang berumur produktif (14 - 64 tahun) dibandingkan dengan petani non produktif (Usia muda dan Usia tua) dapat dilihat pada diagram berikut :

\section{Usia Produktif dan Non Produktif}

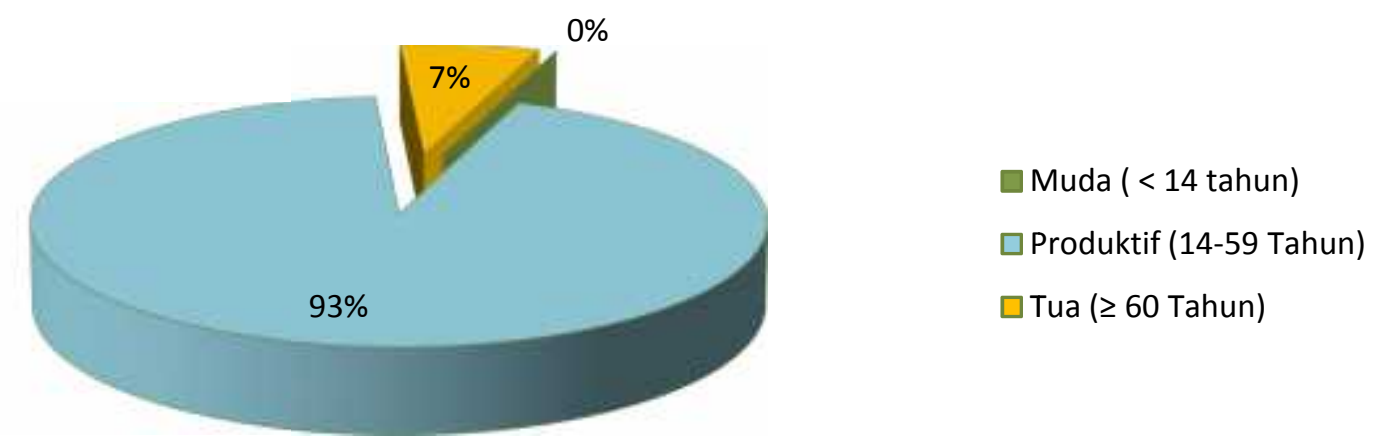

Sumber : Analisis Data Primer, 2012 (data diolah)

\section{Gambar 1. Persentase Usia Produktif dan Produktif Responden}

Pada diagram 1 di atas dapat kita lihat bahwa tenaga kerja usia produktif pada daerah penelitian berjumlah 28 orang atau sekitar $93 \%$ dari jumlah responden.sedangkan penduduk usia non produktif berjumlah 2 orang atau sekitar $7 \%$. Sehingga dengan demikian, penduduk usia produktif yang tinggi diharapkan dapat memberikan sumbangan yang besar terhadap peningkatan produksi yang pada digilirannya akan memberikan peningkatan pendapatan bagi petani yang berada disekitar kawasan hutan.

\section{Tingkat Pendidikan}

Berdasarkan hasil penelitian diketahui bahwa tingkat pendidikan responden diukur berdasarkan tingkat pendidikan formal yang pernah diikuti. Kategori pendidikan responden dibagi ke dalam 3 tingkatan, yaitu rendah (SD), sedang/menengah (SMP), dan tinggi (SMA dan perguruan tinggi). Adapun hasil penelitian tentang tingkat pendidikan responden dapat dilihat pada diagram berikut. 


\section{Tingkat Pendidikan Responden}

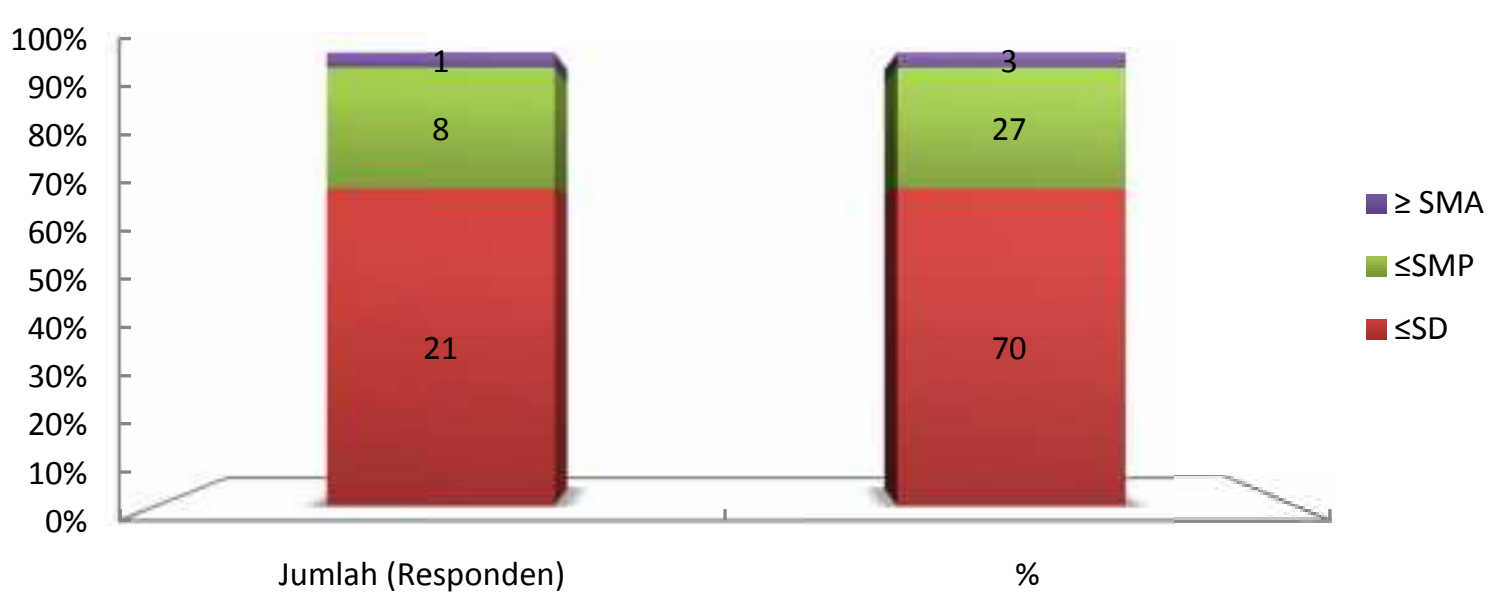

Sumber : Analisis Data Primer, 2012 (data diolah)

\section{Gambar 2. Jumlah dan Persentase Tingkat Pendidikan Responden}

Berdasarkan diagram di atas terlihat bahwa rata-rata sebagian besar responden hanya mengenyam pendidikan sampai sekolah dasar (SD), yaitu sebanyak 21 orang responden atau sekitar $70 \%$ dari total responden. Untuk tingkat pendidikan sedang (SMP) yaitu sebanyak 8 orang atau sekitar $27 \%$, sedangkan untuk tingkat pendidikan atas (SMA dan PT) hanya berjumlah 1 orang atau sekitar $3 \%$ ).

Data yang diperoleh menunjukkan bahwa tingkat pendidikan responden di Kecamatan Sejangkung Kabupaten Sambas masih rendah. Melihat kondisi pendidikan responden yang masih sangat rendah tersebut, dikhawatirkan nantinya mereka tidak akan dapat memelihara lahan usahataniya dengan baik dan mempunyai pola pikir untuk membuka lagi lahan-lahan baru di sekitar hutan untuk dijadikan lahan usahataniya. Oleh sebab itu, sangat diharapkan adannya bantuan dari pihak-pihak terkait untuk memberikan penyuluhan kepada masyarakat atau petani setempat agar mereka lebih bijaksana lagi dalam mengelola lahan usahataninya.

\section{Pengalaman Berusahatani}

Pengalaman usahatani adalah lamanya petani menekuni kegiatan usahataninya. Tohir (1991) mengatakan bahwa semakin lama seorang petani dalam mengelola usahataninya, maka semakin banyak pengalaman yang diperoleh. Pengalaman tersebut tentunya akan banyak mempengaruhi sikap dan tindakan petani dalam pengambilan keputusan usahataninya. Berdasarkan data yang diperoleh menunjukkan bahwa mayoritas petani memiliki pengalaman berusahatani di atas 20 tahun. Adapun hasil selengkapnya disajikan pada diagram 3 berikut ini. 


\section{Pengalaman Berusahatani}

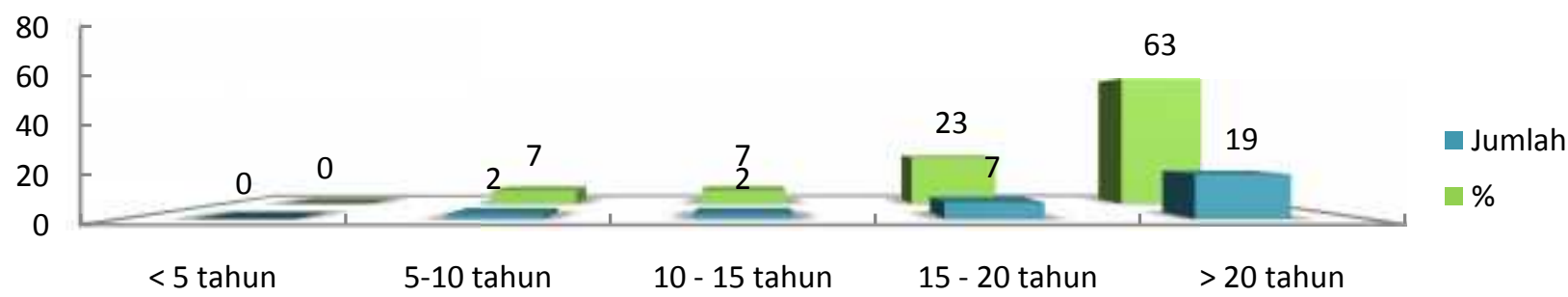

Sumber : Analisis Data Primer, 2012 (data diolah)

\section{Gambar 3. Jumlah dan Persentase Pengalaman Berusahatani Responden}

Diagram di atas memperlihatkan bahwa persentase terbesar yang dimiliki petani responden adalah pengalaman berusahatani di atas 20 tahun, yaitu sebesar $63 \%$. Hal ini mengiindikasikan bahwa kegiatan berusahatani di sekitar kawasan hutan di Kecamatan Sejangkung Kabupaten Sambas telah lama diusahakan bahkan bersifat turun-temurun.

\section{.4 Jumlah Tanggungan Keluarga}

Jumlah tanggungan keluarga merupakan banyaknya orang yang ditanggung oleh kepala keluarga. Di dalam satu rumah tangga dapat terdiri dari suami, istri, anak, orangtua (suami atau istri) atau orang lain yang menjadi tanggungan keluarga. Di dalam penelitian ini karakteristik jumlah tanggungan keluarga dibagi berdasarkan kriteria yang disampaikan oleh Tohir (1991), yaitu jumlah tanggungan keluarga kecil (<3 orang) dan jumlah tanggungan keluarga sedang ( $3-5$ orang) dan besar $>5$ orang. Jumlah tanggungan keluarga petani dapat dilihat pada diagram 4 berikut.

\section{Jumlah Tanggungan Keluarga Responden}

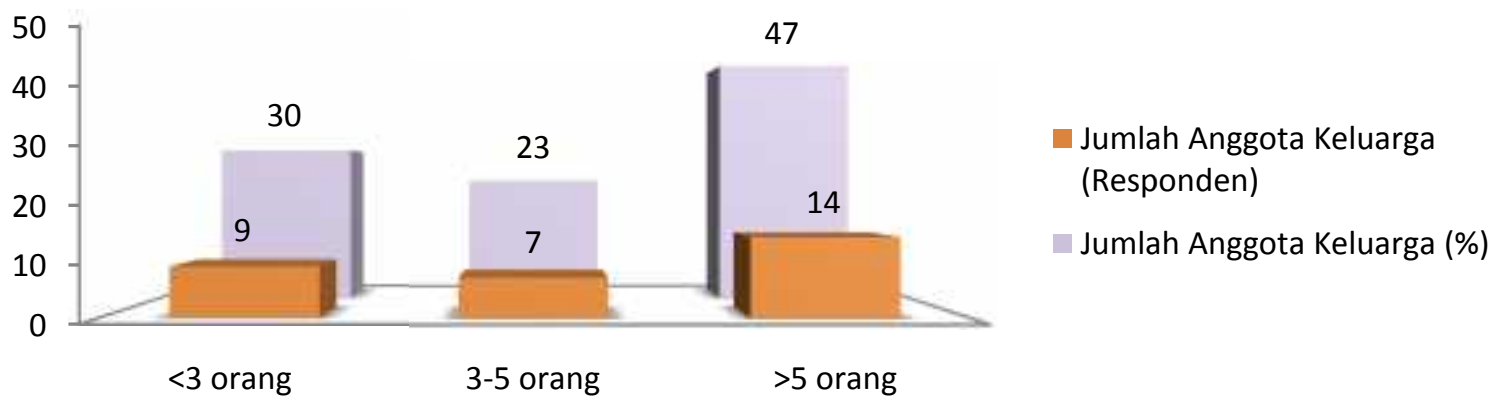

Sumber : Analisis Data Primer, 2012 (data diolah)

Gambar 4. Jumlah dan Persentase Tanggungan Keluarga Responden 
Diagram di atas memperlihatkan bahwa jumlah petani responden dengan jumlah tanggungan keluarga berturut-turut adalah keluarga besar ( $>5$ orang) berjumlah 14 responden atau sebesar $47 \%$, keluarga kecil ( $<3$ orang) berjumlah 9 responden atau sebesar $30 \%$ dan keluarga sedang (3-5 orang) berjumlah 7 responden atau sekitar $23 \%$.

Jumlah tanggungan keluarga ini tentunya mencerminkan beban ekonomi (sandang, pangan, papan dan pendidikan) yang harus ditanggung oleh seorang petani. Semakin banyak jumlah tanggungan keluarga petani, maka semakin besar penghasilan yang diharapkan petani guna mencukupi kebutuhan semua tanggungan keluarganya. Hal ini akan mempengaruhi petani dalam pengambilan keputusan usahataninya. Jumlah tanggungan keluarga merupakan salah satu indikator dalam menentukan aktivitas petani sehingga akan memaksa petani dalam melakukan aktivitas-aktivitas lain dalam menunjang kehidupan keluarga yang menjadi tanggung jawabnya sebagai kepala keluarga.

\subsubsection{Luas Lahan Garapan dan Status Kepemilikan}

Luas lahan garapan yang dimiliki oleh petani responden di Kecamatan Sejangkung Kabupaten Sambas terdiri dari pertanian tanaman tanaman pangan yaitu padi dan tanaman perkebunan, yaitu karet. Luas lahan garapan petani responden diklasifikasikan dalam 3 kelompok menurut luas lahan garapannya, yaitu lahan sempit $\leq$ $0,5 \mathrm{Ha}$, Lahan sedang 0,75 - $1 \mathrm{Ha}$ dan Lahan luas $>1 \mathrm{Ha}$. Selengkapnya data mengenai luas lahan garapan dapat dilihat pada Tabel 1 sebagai berikut:

Tabel 1. Identifikasi Petani Responden Berdasarkan Luas Lahan Garapan di Kecamatan Sejangkung Kabupaten Sambas

\begin{tabular}{|c|c|c|c|c|c|c|c|c|}
\hline \multirow{3}{*}{$\begin{array}{l}\text { KOMODITI YANG } \\
\text { DIUSAHAKAN }\end{array}$} & \multicolumn{6}{|c|}{ LUAS LAHAN } & & \\
\hline & \multicolumn{2}{|c|}{$<0,5 \mathrm{Ha}$} & \multicolumn{2}{|c|}{$0,5-1$} & \multicolumn{2}{|c|}{$>1 \mathrm{Ha}$} & \multicolumn{2}{|c|}{ JUMLAH } \\
\hline & Jumlah & $\%$ & Jumlah & $\%$ & Jumlah & $\%$ & jumlah & $\%$ \\
\hline Padi & 1 & 0 & 8 & 27 & 21 & 70 & 30 & 100 \\
\hline Karet dan Kelapa & 0 & 0 & 9 & 30 & 21 & 70 & 30 & 100 \\
\hline TOTAL Luas & 1 & 0 & 17 & 57 & 42 & 140 & 60 & 200 \\
\hline
\end{tabular}

Sumber : Analisis Data Primer 2012 (Data diolah).

Berdasarkan data di atas dapat dilihat bahwa komoditi yang diusahakan oleh masyarakat atau petani sekitar hutan di Kecamatan Sejangkung Kabupaten Sambas adalah Padi sebagai tanaman pangan dan Karet sebagai tanaman perkebunan. Adapun luas lahan garapan yang diusahakan untuk komoditas padi yang terbanyak diusahakan adalah dengan luas lahan $>1$ ha yaitu sebanyak 21 responden atau sebesar $70 \%$, sedangkan untuk tanaman karet yang terbanyak juga $>1$ ha, yaitu diusahakan sebanyak 21 responden atau sekitar $70 \%$.

Adapun status kepemilikan lahan berdasarkan data yang diperoleh. sebanyak 24 responden atau sekitar $80 \%$ yang mengusahakan lahan usahataninya di atas lahan milik sendiri dan sebanyak 6 orang atau $20 \%$ dengan status sewa/sakap.

\section{Gambaran Kondisi Pertanian dan Kehidupan Sosial Ekonomi Petani Responden}

1 Kegiatan Pembukaan Lahan dan Budidaya Pertanian

Hutan sebagai sumberdaya alam memberikan manfaat bagi kelangsungan hidup manusia, baik secara langsung maupun tidak langsung. Untuk mempertahankan manfaat 
hutan tersebut diperlukan usaha-usaha pengelolaan yang baik (Gendon dan Wisnu, 1994). Peranan masyarakat dalam ekosistem hutan mempunyai hubungan yang unik, usaha masyarakat untuk menjamin kebutuhan hidupnya pada saat sekarang telah menyebabkan pergeseran atau perubahan ekosistem yang tidak menguntungkan bagi kehidupan selanjutnya sebagai faktor penyebab perubahan harus mendapat perhatian khusus, karena berhasil atau tidaknya kelestarian hutan ditentukan sejauh mana keadaan masyarakat dapat diperbaiki (Arifin A, 2001).

Di Kecamatan Sejangkung Kabupaten Sambas, Penduduknya sebagian besar tinggal di daerah pedesaan dengan mengandalkan usaha pertanian sebagai pendapatan pokok. Pertambahan jumlah penduduk yang tinggi dan terbatasnya jumlah lahan telah mengakibatkan persaingan peruntukkan lahan hutan menjadi lahan pertanian atau peruntukkan lainnya. Pada awalnya hutan sebagai rehabilitasi lahan dan konservasi tanah dimanfaatkan oleh masyarakat di sekitar kawasan hutan sebagai potensi lahan pertanian dalam rangka memenuhi kebutuhan hidupnya. Desakan kebutuhan ekonomi masyarakat akan pangan dan sandang dirasakan sangat tidak mencukupi. Hutan kemudian dibuka menjadi lahan pertanian sebagai hutan rakyat yang diusahakan oleh masyarakat di sekitar hutan itu sendiri secara tradisional dan turun-temurun. Mereka ada yang membuka hutan sendiri-sendiri ataupun dengan kelompok keluarga pemilik lahan itu sendiri, yaitu Ayah dan anak laki-laki mereka, biasanya mereka bersepakat 4-5 orang membentuk kelompok menyelesaikan pembukaan lahan. Kegiatan pembukaan lahan merupakan kelanjutan dari penebangan hutan, dimana pohon yang masih tersisa ditebagi. Pohon yang tidak terlalu besar ditebang untuk kebutuhan kayu bakar, kemudian semak belukar yang ada ditebas dan dikumpulkan lalu dibakar. Pada saat musim hujan turun lahan tersebut dicangkul dan siap untuk ditanami. Lahan yang telah siap ditanami tersebut pada tahap awal biasanya ditanami tanaman pangan seperti Padi sayur-sayuran (tanaman musiman), Ubi kayu, dan ubi Jalar Selanjutnya ditanami dengan tanaman perkebunan atau tanaman tahunan seperti Karet dan Kelapa.

Cara bercocok tanam/bertani masyarakat di kawasan sekitar hutan di kecamatan sejangkung kabupaten Sambas masih bersifat tradisional dengan peralatan dan sarana produksi usahatani yang masih sederhana. Seperti penggunaan bibit Padi lokal, pemakaian pupuk kandang dan pupuk anorganik (Urea, TSP, KCL).

Pemeliharaan tanaman, baik tanaman pangan maupun tanaman perkebunan dilakukan oleh petani di sekitar hutan secara intensif, mulai dari penanaman sampai dengan panen. Khusus untuk tanaman tahunan setelah diproduksi dilakukan pemeliharaan hanya pada saat-saat tertentu, yaitu pada saat mereka membersihkan

kebun. Pengunaan pupuk dan obat-obatan (insektisida) oleh petani responden di sekitar hutan di Kecamatan Sejangkung Kabupaten Sambas sangat kurang bahkan tidak ada.

\section{Mata Pencaharian}

Keseluruhan Populasi Petani responden di Kecamatan Sejangkung Kabupaten Sambas bermata pencaharian sebagai petani di sekitar kawasan hutan untuk memenuhi kebutuhan hidup sehari-hari. Kadangkala di waktu menunggu masa panen Padi, mereka dan beberapa anggota keluarganya ada yang bekerja sampingan sebagai buruh ataupun sebagai tenaga penambang emas di dekat kawasan tersebut.

\section{Pemasaran Hasil Produksi Pertanian}

Kegiatan pemasaran hasil produksi pertanian yang dilakukan oleh masyarakat di sekitar hutan di Kecamatan Sejangkung Kabupaten Sambas yaitu : 
1.Dijual ke pedagang pengumpul, yaitu pemasaran hasil produksi kepada pedagang pengumpul. Biasanya para pedagang pengumpul tersebut akan memasarkan kepada pedagang di tingkat kabupaten ataupun di pedagang tingkat propinsi. Sistem pemasaran ini didasarkan pada hubungan kekeluargaan atau karena pedagang pengumpul sering membantu petani apabila mengalami kesulitan ekonomi.

2.Petani memasarkan langsung hasil produksinya dengan membawa hasil produksi ke pasar kecamatan atau ke pasar kabupaten tanpa melalui pedagang perantara atau pengumpul.

\section{Modal dan Tenaga Kerja}

Modal yang digunakan oleh petani umumnya berasal dari milik pribadi atau sendiri. Adapun petani responden yang mengalami kesulitan dalam permodalan usahatani biasanya meminjam modal usahatani dari keluarganya ataupun dari pedagang pengumpul yang datang. Untuk tenaga kerja umumnya semua petani responden menggunakan tenaga kerja manusia yang berasal dari dalam keluarga (anggota keluarga) dan tidak ada yang menggunakan tenaga kerja ternak ataupun mesin. Untuk tenaga kerja yang berasal dari tenaga kerja luar keluarga biasanya diperlukan pada saat pembukaan lahan dan musim panen.

\section{Pendapatan Usahatani}

Kegiatan usahatani yang dilakukan oleh masyarakat di sekitar kawasan hutan di Kecamatan Sejangkung Kabupaten Sambas masih bersifat tradisional dan subsisten, terutama tanaman pangan (padi). Hasil tanaman padi sebagian digunakan untuk keperluan konsumsi dan sebagian lagi biasanya di jual ke pasar ataupun pedagang pengumpul. Sedangkan untuk tanaman perkebunan seperti Karet dan Kelapa diperuntukan untuk usahatani komersial. Rata-rata pendapatan petani responden di sekitar kawasan hutan di Kecamatan Sejangkung Kabupaten Sambas berkisar antara Rp. 500.000 - Rp. 3.000.000 per bulan. Dengan nilai rata-rata pendapatan untuk keseluruhan responden sebesar Rp. 1.436.667. Besarnya nilai pendapatan petani ini tergantung pada luasnya lahan garapan dan produksi yang dihasilkan oleh petani.

Adapun jumlah dan pendapatan petani responden dengan kategori rendah, sedang dan tinggi dapat dilhat pada Diagram 5 berikut.

\section{Pendapatan Petani}

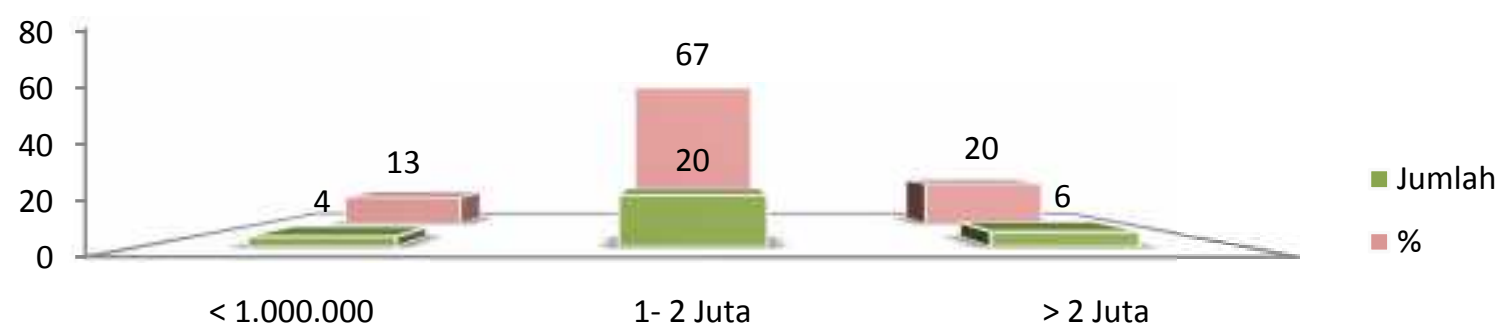

Sumber : Analisis Data Primer 2012, (Data diolah).

Gambar 5. Jumlah dan Persentase Pendapatan Petani Responden 
Berdasarkan data di atas dapat terlihat bahwa rata-rata mayoritas pendapatan petani di sekitar hutan di kecamatan Sejangkung kabupaten Sambas masih tergolong menengah ke bawah sampai rendah, apalagi ditambah dengan banyaknya jumlah tanggungan keluarga yang menjadi tanggungjawab petani, mengakibatkan distribusi pendapatan dalam rangka memenuhi kebutuhan hidupnya dan anggota keluarganya masih sangat rendah.

\section{Hasil Analisis Regresi Faktor-Faktor Yang Mempengaruhi Tingkat Pendapatan Petani Responden}

Hasil analisis regresi berganda mengenai faktor-faktor produksi yang mempengaruhi usahatani lidah buaya diperlihatkan pada tabel 7. Pada model analisis regresi linier berganda, variabel dependen (terikat) yang digunakan adalah pendapatan $\left(\mathrm{y}_{\mathrm{i}}\right)$, sedangkan variabel independen (bebas) adalah Umur $\left(\mathrm{X}_{1}\right)$, tingkat pendidikan $\left(\mathrm{X}_{2}\right)$, jumlah tanggungan keluarga $\left(X_{3}\right)$, pengalaman $\left(X_{4}\right)$, Luas lahan garapan $\left(X_{5}\right)$, Modal $\left(X_{6}\right)$ dan tenaga kerja $\left(X_{7}\right)$. Analisis regresi linier berganda digunakan dengan alat bantu analisis software SPSS 17.

Tabel 8. Faktor - Faktor Yang Mempengaruhi Pendapatan Usahatani di Sekitar Hutan di Kecamatan Sejangkung Kabupaten Sambas Kalimantan Barat

\begin{tabular}{lcc}
\hline \multicolumn{1}{c}{ Variable } & \multicolumn{2}{c}{ Pendapatan $\left(\mathrm{Y}_{\mathrm{i}}\right)$} \\
\cline { 2 - 3 } & Coefficient & Prob. \\
\hline UMUR $\left(\mathrm{X}_{1}\right)$ & $-1.006^{\mathrm{TS}}$ & 0.325 \\
PENDIDIKAN $\left(\mathrm{X}_{2}\right)$ & $0.422^{\mathrm{TS}}$ & 0.677 \\
JUMLAH TANGGUNGAN KELUARGA $\left(\mathrm{X}_{3}\right)$ & $0.010^{\mathrm{TS}}$ & 0.992 \\
PENGALAMAN $\left(\mathrm{X}_{4}\right)$ & $0.696 \mathrm{t}^{\mathrm{TS}}$ & 0.494 \\
LUAS LAHAN & $2.630^{\star \star *}$ & 0.015 \\
MODAL & $3.152^{\star \star *}$ & 0.005 \\
TENAGA KERJA & $0.553^{\mathrm{TS}}$ & 0.586 \\
C & $-0.143^{\mathrm{TS}}$ & 0.888 \\
R-squared & .722 & \\
Adjusted R-squared & .633 & \\
S.E. of regression & 285554.095 & \\
Sum squared resid & 1.794 & \\
Log likelihood & 106.5001 & \\
Durbin-Watson stat & 1.474 & \\
F-statistic & 8.145 & \\
Prob(F-statistic) & 0.00001 & \\
\hline Sumber : Analsis Data Primer, & \\
\end{tabular}

Sumber : Analisis Data Primer, 2012

Keterangan :

*** = signifikan pada tingkat kepercayaan $99 \%$

** = signifikan pada tingkat kepercayaan $95 \%$

* = signifikan pada tingkat kepercayaan $90 \%$

NS = tidak signifikan

Hasil analisis regresi linear berganda memperlihatkan nilai koefisien determinasi $\left(R^{2}\right)$ sebesar 0,722 . Angka ini menyatakan bahwa variabel - variabel independen seperti IUmur $\left(X_{1}\right)$, tingkat pendidikan $\left(X_{2}\right)$, jumlah tanggungan keluarga $\left(X_{3}\right)$, pengalaman $\left(X_{4}\right)$, Luas lahan garapan $\left(X_{5}\right)$, Modal $\left(X_{6}\right)$ dan tenaga kerja $\left(X_{7}\right)$ secara simultan mampu menjelaskan variabel produksi sebesar $72,2 \%$ dan, sedangkan sisanya diterangkan oleh 
variabel lain di luar model. Hasil uji $F$, menunjukkan nilai $F_{\text {hitung }}$ sebesar 8,145 dengan probabilitas 0,000001. Oleh karena nilai $F_{\text {hitung }}>F_{\text {tabel }}(2,95)$ pada tingkat kepercayaan 99 $\%$, maka Ho ditolak. Hal ini mengindikasikan bahwa variabel Umur $\left(X_{1}\right)$, tingkat pendidikan $\left(X_{2}\right)$, jumlah tanggungan keluarga $\left(X_{3}\right)$, pengalaman $\left(X_{4}\right)$, Luas lahan garapan $\left(X_{5}\right)$, Modal $\left(X_{6}\right)$ dan tenaga kerja $\left(X_{7}\right)$ secara bersama - sama (simultan) berpengaruh nyata terhadap pendapatan. Hasil Uji t memperlihatkan bahwa variabel bebas yang berpengaruh secara signifikan terhadap pendapatan usahatani yaitu luas lahan garapan $\left(X_{5}\right)$ dan modal $\left(X_{6}\right)$. Variabel bebas yang tidak berpengaruh signifikan terhadap pendapatan usahatani yaitu Umur $\left(\mathrm{X}_{1}\right)$, tingkat pendidikan $\left(\mathrm{X}_{2}\right)$, jumlah tanggungan keluarga $\left(X_{3}\right)$, pengalaman $\left(X_{4}\right)$, dan tenaga kerja $\left(X_{7}\right)$.

\section{PENUTUP}

\section{Simpulan}

Berdasarkan hasil pembahasan tentang identifikasi dan inventarisasi usaha agribisnis di sekitar kawasan hutan di Kecamatan Sejangkung Kabupaten Sambas. Maka dapat diambil kesimpulan sebagai berikut :

1. Kegiatan usahatani yang dilakukan oleh masyarakat di sekitar hutan bersifat tradisional dan semi-subsisten terutama untuk tanaman pangan (padi), ternak ayam dan bersifat komersial untuk tanaman Karet dan kelapa.

2. Corak pertanian masyarakat di sekitar hutan masih bersifat turun-temurun, tradisional dan, menggunakan tenaga kerja dalam keluarga, modal sendiri dan hasil pertaniannya di pasarkan/di jual ke pedagang pengumpul ataupun langsung di jual ke pasar tingkat Kecamatan ataupun tingkat Kabupaten.

3. Pendapatan Usahatani masyarakat di sekitar hutan di kecamatan Sejangkung kabupaten Sambas masih tergolong menengah ke bawah sampai rendah dengan tingkat pendapatan terendah Rp. 500.000/bulan dan tertinggi Rp. 3.000.000/bulan, dengan rata-rata total pendapatan per responden 1.436.667/bulan.

4. Hasil analisis regresi faktor-faktor yang mempengaruhi pendapatan usahatani yang berpengaruh positif dan signifikan adalah Luas lahan dan Modal. Sedangkan tingkat pendidikan, jumlah tanggungan keluarga, pengalaman dan tenaga kerja berpengaruh positif namun tidak signifikan. Umur responden berpengaruh negatif dan tidak signifikan terhadap pendapatan petani.

\section{Saran}

1. Dalam rangka menjaga kelestarian dan pemanfaatan sumberdaya alam hutan secara lebih bijaksana, perlu adanya perubahan tentang sistem usahatani/agribisnis mereka melalui kegiatan penyuluhan dari instansi pemerintah ataupun yang terkait.

2. Perlu adanya bantuan pemerintah seperti bibit, pupuk, modal, ataupun peralatan dalam rangka meningkatkan usahatani masyarakat di sekitar hutan di Kecamatan Sejangkung Kabupaten Sambas. 


\section{DAFTAR PUSTAKA}

Arifin, A. 2001. Hutan dan Kehutanan. Kanisius, Yogyakarta.

Dinas Kehutanan Provinsi Kalimantan Barat. 1999. Statistik Kehutanan. Dephut KALBAR. Nazir, M. 1988. Metode IImiah. Penerbit Ghalia. Jakarta.

Tohir, K.A. 1991. Seuntai Pengetahuan Usahatani Indonesia. Rineka Cipta. Jakarta.

Widarjono, Agus. 2005. Ekonometrika : Teori dan Aplikasi untuk Ekonomi dan Bisnis. Penerbit Ekonisia Fakultas Ekonomi UII. Yogyakarta.

Widyastuti, Y.E. 2000. Usahatani Terpadu Ternak dan Tanaman. Penebar Swadaya, Jakarta 